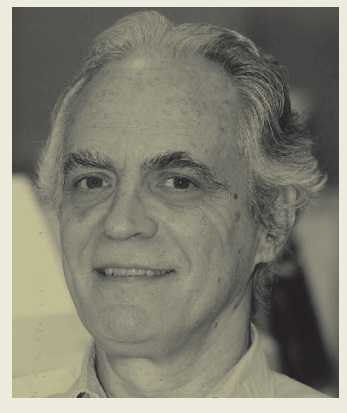

\title{
A CAMPANHA ELEITORAL E O AJUSTE FISCAL
}

Dizem que o Planalto terceirizou o serviço de café, pois em governo que acaba nem a bebida é servida. De fato, depois da desistência de votar a reforma da previdência, a caça aos votos nas próximas eleições tornou-se o estribilho da moda em Brasília: abram só a caixa de ferramentas das bondades! A contaminação é tanta que até mesmo Michel Temer parece arvorar-se candidato.

Apesar disso, a economia momentaneamente não se abalou. Por um lado, a confirmação da sentença aumentada de Lula e a inviabilidade de sua candidatura tranquilizaram os donos do produto interno bruto (PIB) quanto à ameaça da volta do populismo gastador estilo Dilma Rousseff. Por outro, os preços firmes das exportações e a repetição de uma boa safra - garantindo inflação baixa - são elixires que neutralizam por algum tempo o desequilíbrio fiscal.

Mas esta misteriosa entidade - $o$ tempo-, embora eterna, inexoravelmente passa. O próximo governo, independentemente de qual seja, será obrigado a consumar o ajuste fiscal. A alternativa é a volta da inflação acompanhada de recessão, poderosos ingredientes para um impeachment.

No curto prazo, o pequeno crescimento das receitas tributárias brindadas pelo titubeante crescimento do PIB e a redução das despesas com juros da dívida pública, viabilizada pela queda da Selic, animam, mas não resolvem. O governo precisa de muito mais. É indispensável zerar o deficit primário, transformá-lo em superavit e reduzir o deficit nominal. Assim, chega-se ao equilíbrio fiscal, esvaziando a pressão sobre o crescimento da dívida pública.

A reforma da previdência é passo imprescindível. Mas fica cada vez mais claro que, mesmo um improvável resultado otimista - no sentido de reduzir as despesas, o que inclui o combate ao desperdício-, será insuficiente para obter tal equilíbrio.

Resta a alternativa clássica: expandir a receita tributária, seja aumentando os tributos existentes, seja criando novos.

Certamente, nenhum candidato à presidência com pretensões de vitória trafegará por essa avenida. No máximo, os mais ousados inclinar-se-ão por redistribuir a mesma carga, aliviando os mais pobres e exigindo dos mais ricos maior contribuição; ou, em linguagem tributária, diminuindo a carga dos impostos indiretos e aumentando a dos diretos.

Embora correta, essa postura esbarra no que poderíamos chamar de linha de menor resistência: é mais fácil aumentar um imposto que se espalha por todo o mundo - como o incidente sobre os combustíveis - do que um destinado a desabar sobre um grupo, ainda mais tratando-se de poderosos, como é o caso do imposto sobre grandes fortunas.

Uma conjuntura de inflação baixa como a atual favorece a adoção da primeira alternativa: os inevitáveis repasses aos preços acomodam-se no ninho formado por uma eventual deflação dos alimentos e ninguém se machuca.

A pior alternativa seria a vitória de uma candidatura presidencial que, não comprometida declaradamente com o ajuste fiscal e temerosa da acusação de estelionato eleitoral, deixe de tomar as medidas impopulares necessárias e acredite numa subida natural da maré a partir do crescimento que se ensaia em 2018. Quando a maré sobe, todos os barcos a acompanham, é verdade. Porém quem não tem barco acaba morrendo afogado. 